\title{
N-Methylphthalimide-substituted benzimidazolium salts and PEPPSI Pd-NHC complexes: synthesis, characterization and catalytic activity in carbon-carbon bond-forming reactions
}

\author{
Senem Akkoç ${ }^{* 1,2, \S}$, Yetkin Gök ${ }^{3}$, İlhan Özer İlhan ${ }^{2}$ and Veysel Kayser ${ }^{* 1} 1, \pi$
}

\author{
Full Research Paper \\ Address: \\ ${ }^{1}$ Faculty of Pharmacy, The University of Sydney, 2006 Sydney, \\ Australia, ${ }^{2}$ Department of Chemistry, Faculty of Sciences, Erciyes \\ University, Talas Street, 38039 Kayseri, Turkey and ${ }^{3}$ Department of \\ Chemistry, Faculty of Arts and Sciences, Inönü University, 44280 \\ Malatya, Turkey \\ Email: \\ Senem Akkoç* - senem.akkoc@sydney.edu.au; Veysel Kayser ${ }^{*}$ - \\ veysel.kayser@sydney.edu.au \\ * Corresponding author \\ § Tel: +61 29351 2330; Tel: +90 35243752 62; Fax: +90 35243749 \\ 33 \\ II Tel: +61 29351 3391; Fax: +61293514391 \\ Keywords: \\ arylation; benzimidazolium salts; catalysis; N-heterocyclic carbene; \\ PEPPSI complex; Suzuki-Miyaura cross-coupling reaction \\ Beilstein J. Org. Chem. 2016, 12, 81-88. \\ doi:10.3762/bjoc. 12.9 \\ Received: 07 November 2015 \\ Accepted: 05 January 2016 \\ Published: 15 January 2016 \\ This article is part of the Thematic Series "N-Heterocyclic carbenes". \\ Guest Editor: S. P. Nolan \\ (C) 2016 Akkoç et al; licensee Beilstein-Institut. \\ License and terms: see end of document.
}

Open Access

\begin{abstract}
A series of novel benzimidazolium salts (1-4) and their pyridine enhanced precatalyst preparation stabilization and initiation (PEPPSI) themed palladium $N$-heterocyclic carbene complexes $\left[\mathrm{PdCl}_{2}(\mathrm{NHC})(\mathrm{Py})\right](\mathbf{5}-\mathbf{8})$, where $\mathrm{NHC}=1-(N$-methylphthalimide)3-alkylbenzimidazolin-2-ylidene and $\mathrm{Py}=3$-chloropyridine, were synthesized and characterized by means of ${ }^{1} \mathrm{H}$ and ${ }^{13} \mathrm{C}\left\{{ }^{1} \mathrm{H}\right\}$ NMR, UV-vis (for 5-8), ESI-FTICR-MS (for 2, 4, 6-8) and FTIR spectroscopic methods and elemental analysis. The synthesized compounds were tested in Suzuki-Miyaura cross-coupling (for 1-8) and arylation (for 5-8) reactions. As catalysts, they demonstrated a highly efficient route for the formation of asymmetric biaryl compounds even though they were used in very low loading. For example, all compounds displayed good catalytic activity for the $\mathrm{C}-\mathrm{C}$ bond formation of 4-tert-butylphenylboronic acid with 4-chlorotoluene.
\end{abstract}

\section{Introduction}

The use of N-heterocyclic carbenes (NHCs) as ligands was started by Wanzlick [1] and Öfele [2] almost fifty years ago. There have been major advances in the design and synthesis of metal complexes containing N-heterocyclic carbene ligands in the last two decades, and they had a wide range of applications in different fields, particularly in homogeneous/heterogeneous catalysis [3-8] and bioorganometallic chemistry [9-11]. This is because NHC complexes are easily obtained by deprotonating 
imidazolium or benzimidazolium salts and most are relatively stable in air and moisture. They are weak $\pi$-acceptors and strong $\sigma$-donors and can form strong $\mathrm{M}-\mathrm{C}$ bonds with transition metal ions compared to trivalent phosphine ligands $[12,13]$.

As catalysts, palladium N-heterocyclic carbene ( $\mathrm{Pd}-\mathrm{NHC})$ complexes display remarkable activities in coupling reactions $[5,14-$ 17]. Among various $\mathrm{Pd}-\mathrm{NHC}$ complexes such as $[\mathrm{Pd}(\mathrm{NHC})(\mathrm{dmba}) \mathrm{Cl}](\mathrm{dmba}=N, N$-dimethylbenzylamine $)$ and $\left[\mathrm{Pd}(\mathrm{NHC})(\mathrm{Im}) \mathrm{Cl}_{2}\right](\mathrm{Im}=$ imidazole $)[18,19]$, [PEPPSI $\mathrm{Pd}-\mathrm{NHC}]$ complexes are prevalent due to the combination of efficiency and versatility $[20,21]$. The synthesis conditions for these complexes are generally mild and do not require an inert atmosphere. The steric and electronic parameters are also easily modified by attaching substituents. PEPPSI Pd-NHC complexes have been used in different coupling reactions such as Mizoroki-Heck cross-coupling [22,23], Suzuki-Miyaura cross-coupling [24,25], Sonogashira [26] and arylation reactions [27].

There are suitable precatalyst scaffolds, which were developed by Nolan [28], Organ [21] and Buchwald [29]. To find more effective catalysts containing an Organ type scaffold among these precatalyst scaffolds, we synthesized four new pure $\mathrm{N}$-methylphthalimide substituted benzimidazolium salts (1-4) and their PEPPSI Pd-NHC complexes (5-8) in this study. The structures of all compounds were confirmed by various spectroscopic methods $\left({ }^{1} \mathrm{H}\right.$ and ${ }^{13} \mathrm{C}\left\{{ }^{1} \mathrm{H}\right\}$ NMR, UV-vis, ESIFTICR-MS, FTIR) and elemental analysis. The PEPPSI $\mathrm{Pd}-\mathrm{NHC}$ complexes were tested for catalytic activities both in direct arylation and Suzuki-Miyaura cross-coupling reactions. The catalytic activities of benzimidazolium salts were only tested in a Suzuki-Miyaura cross-coupling reaction. The compounds were found to be very efficient in the symmetric and asymmetric $\mathrm{C}-\mathrm{C}$ bond-forming reactions.

\section{Results and Discussion Synthesis of $\mathrm{N}$-methylphthalimide substituted benzimidazolium salts}

New benzimidazolium salts $\mathbf{1 - 4}$, which are carbene precursors, were synthesized by $N$-alkylbenzimidazole and various alkyl halides in DMF (Scheme 1). These salts, especially containing benzyl and 3-methylbenzyl groups, were obtained in very high yields (81-97\%) as white or cream solids. The salt containing the 2-morpholinoethyl group was obtained in a much lower yield of $62 \%$.

The benzimidazolium salts include an acidic NCHN proton, which can be deprotonated easily to form an NHC, at the $\mathrm{C} 2$ position of the benzimidazole ring. The sharp salt peak indicating the synthesis of a benzimidazolium salt came quite downfield at $\delta 10.13,11.10,9.65$ and $10.83 \mathrm{ppm}$ in the ${ }^{1} \mathrm{H}$ NMR spectra for $\mathbf{1 - 4}$, respectively. The NCHN peaks of the carbene precursors were observed at $\delta 144.56,144.69,143.55$ and $145.26 \mathrm{ppm}$ in the ${ }^{13} \mathrm{C}\left\{{ }^{1} \mathrm{H}\right\}$ NMR spectra for $\mathbf{1 - 4}$, respectively. The formation of the benzimidazolium salts was also evident through their IR spectra, which showed peaks at 1562.2, $1558.4,1562.2$ and $1554.5 \mathrm{~cm}^{-1}$ for the $v_{(\mathrm{CN})}$ bond of $\mathbf{1 - 4}$, respectively. Compounds $\mathbf{2}$ and $\mathbf{4}$ among these salts were further characterized by using high-resolution mass spectrometry (HRMS). The mass spectra demonstrated $\mathrm{m} / \mathrm{z}$ peaks at 382.16 and 391.18 for the cationic moieties against the calculated value of $m / z 382.43$ and 391.44 for $\mathbf{2}$ and $\mathbf{4}$, respectively.

\section{Synthesis of PEPPSI Pd-NHC complexes}

Our aim was to synthesize novel Pd-NHC complexes containing a PEPPSI skeleton. The target PEPPSI Pd-NHC complexes 5-8 were successfully synthesized by using carbene precursors 1-4, $\mathrm{PdCl}_{2}$ and $\mathrm{K}_{2} \mathrm{CO}_{3}$ as a base in 3-chloropyridine (Scheme 1). The colors of the obtained solid complexes were either yellow or cream. These complexes, which are stable both in solution and in solid states against air, light and moisture,

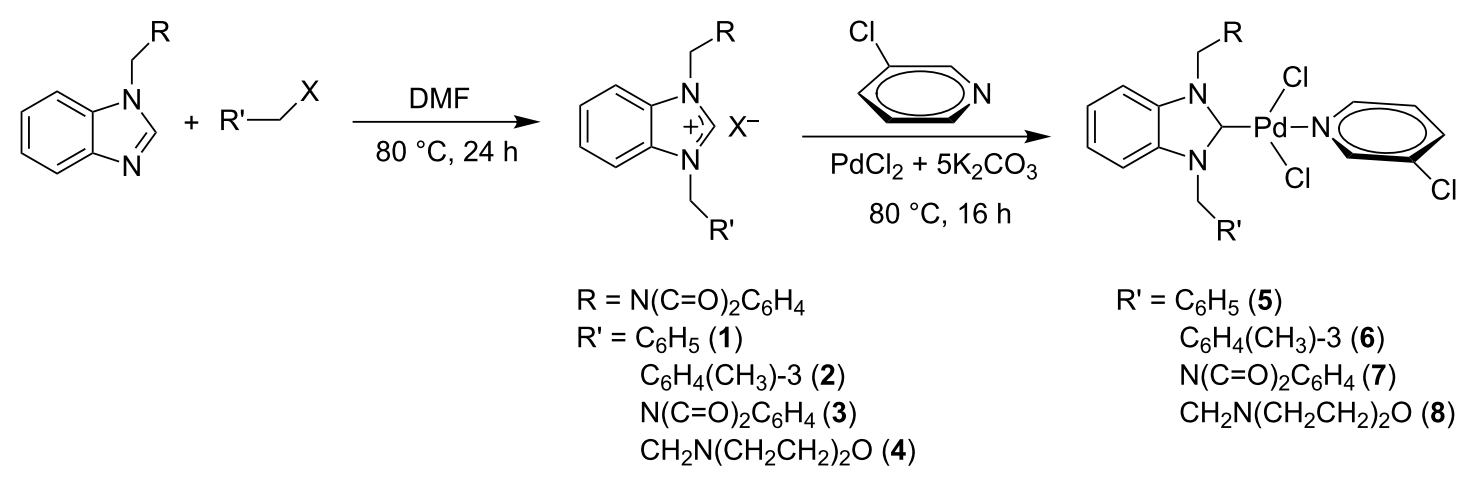


were obtained in low yields of $25-60 \%$. All complexes with a benzimidazolium moiety display characteristic signals for the 3-chloropyridine ligand in the ${ }^{1} \mathrm{H}$ and ${ }^{13} \mathrm{C}\left\{{ }^{1} \mathrm{H}\right\}$ NMR spectra. For the ${ }^{1} \mathrm{H}$ NMR spectra of the metal complexes, sharp peaks in the lower field belonging to the benzimidazolium salts $(\mathrm{NCHN})$ were not observed between $\delta 10$ and $12 \mathrm{ppm}$. The FTIR data clearly indicated the presence of $v_{(\mathrm{CN})}$ at 1508.2, 1446.5, 1394.4 and $1444.6 \mathrm{~cm}^{-1}$ for the PEPPSI Pd-NHC complexes 5-8, respectively. The formation of a $\mathrm{C}-\mathrm{N}$ module in the benzimidazole ring correlated with a shift of IR $(\mathrm{CN})$ band. The complexes 6-8 were further characterized by means of HRMS which showed $\mathrm{m} / \mathrm{z}$ peaks at $637.02,691.99$ and 574.99 for the cationic moieties against the calculated values of $\mathrm{m} / \mathrm{z} 636.84$, 691.84 and 574.95, respectively. Unfortunately, we were unable to yield a proper single crystal from these compounds for X-ray diffraction. Unlike the salts, the metal complexes showed absorbance in UV-vis experiments.

\section{Absorption spectroscopy studies}

The absorption spectra of the complexes were recorded in DMSO and are shown in Figure 1A.

Only metal complexes show an absorbance above $330 \mathrm{~nm}$ and have the highest absorption, whereas salts did not display any absorbance except for an intense peak below $330 \mathrm{~nm}$. Therefore, we only discuss the metal complexes here. For the metal complexes, the spectra are characterized by a broad band between 350 and $430 \mathrm{~nm}$ and display a strong absorption below $350 \mathrm{~nm}$. Complex 5 exhibits the overall highest absorption, whereas the overall absorption of complex 7 seems to be the lowest of the six investigated complexes. Very broad absorp- tion spectra are indicative of a charge transfer, and to deconvolute the shoulder or ripple of the absorption spectra, we applied the second derivative analysis (Figure 1B). The second derivative spectra were noisy, as can clearly be seen after smoothing three positive peaks (at 315, 345 and $430 \mathrm{~nm}$ ) and two negative peaks (at 380 and $405 \mathrm{~nm}$ ). In the second derivative analysis, a negative band has a minimum at the same wavelength as the maximum on the main absorption spectrum. With this in mind, there are at least two absorbance bands buried between $350-430 \mathrm{~nm}$.

\section{Catalytic activity of PEPPSI Pd-NHC com- plexes as catalysts in arylation reaction}

First, we performed the arylation reaction between the 4-bromoacetophenone, which is electron-deficient, with 2-n-butylthiophene without the catalyst at $110{ }^{\circ} \mathrm{C}$ for $1 \mathrm{~h}$ in DMAc as solvent and the reaction resulted in only a $1 \%$ yield. When we attempted the same reaction using 8 as a catalyst at $130{ }^{\circ} \mathrm{C}$, the efficiency of the reaction was $27 \%$ (Table 1 , entry 3 ). For catalyst 5 , the yield dropped to $9 \%$, the temperature was decreased to $110{ }^{\circ} \mathrm{C}$ and the procedure time was increased from $1 \mathrm{~h}$ to $1.5 \mathrm{~h}$ (Table 1 , entry 2 ).

When 4-bromoacetophenone was used as a substrate with catalyst 6, $\mathrm{sp}^{2}-\mathrm{sp}^{2} \mathrm{C}-\mathrm{C}$ bond formation with 2-n-butylfuran was achieved with a yield of $49 \%$ in just $1 \mathrm{~h}$ (Table 1, entry 5 ). The product was obtained in a much lower yield when the same reaction was carried out with $\mathbf{5}$ as a catalyst. Compounds $\mathbf{7}$ and $\mathbf{8}$ as catalysts were displaying better results than complexes $\mathbf{5}$ and 6 for the same reaction (Table 1, entries 6 and 7). When we employed electron-neutral bromobenzene as a substrate instead
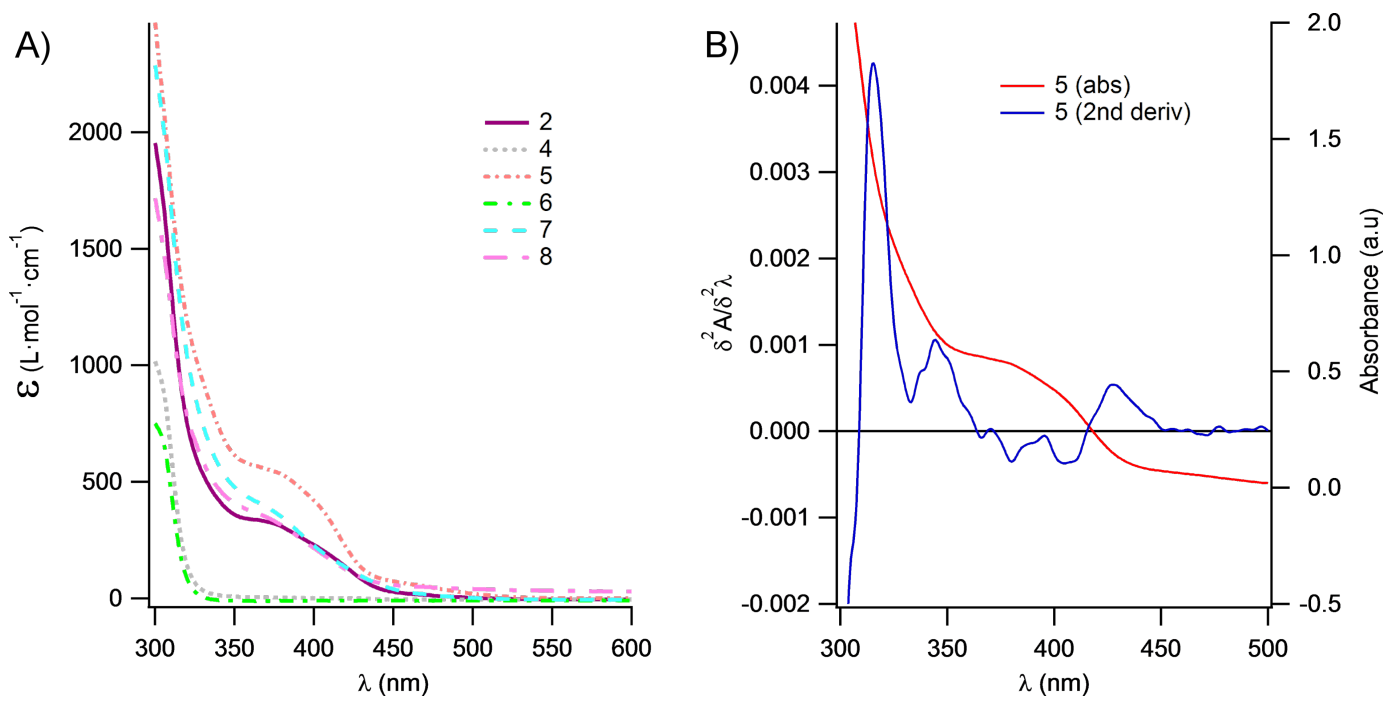

Figure 1: (A) UV-vis absorbance spectra were taken in DMSO. (B) The second derivative of the compound 5 calculated from A. Other metal complexes have similar second derivative bands but are omitted for simplicity. 
Table 1: PEPPSI Pd-NHC catalyzed direct intermolecular arylation of heteroaryl derivatives with various aryl bromides ${ }^{a, b}$

\begin{tabular}{|c|c|c|c|c|c|c|}
\hline Entry & $\mathrm{R}$ & $x$ & Time $(\mathrm{h})$ & Temp. $\left({ }^{\circ} \mathrm{C}\right)$ & Comp. & Yield (\%) \\
\hline 1 & $\mathrm{CH}_{3}(\mathrm{C}=\mathrm{O})-$ & $S$ & 1 & 110 & - & 1 \\
\hline 2 & & & 1.5 & 110 & 5 & 9 \\
\hline 3 & & & 1 & 130 & 8 & 27 \\
\hline 4 & & 0 & 1 & 110 & 5 & 14 \\
\hline 5 & & & 1 & 110 & 6 & 49 \\
\hline 6 & & & 1 & 110 & 7 & 83 \\
\hline 7 & & & 1 & 110 & 8 & 89 \\
\hline 8 & $\mathrm{H}-$ & $S$ & 1 & 110 & 8 & 97 \\
\hline 9 & & 0 & 21 & 80 & 7 & 71 \\
\hline 10 & & & 21 & 90 & 7 & 84 \\
\hline 11 & & & 21 & 110 & 7 & 98 \\
\hline 12 & $\mathrm{CH}_{3} \mathrm{O}-$ & $S$ & 1 & 130 & 5 & 79 \\
\hline
\end{tabular}

aReaction conditions: 2 - $n$-butylthiophene or 2- $n$-butylfuran (2 mmol), 4-bromoacetophenone, bromobenzene or 4-bromoanisole (1 mmol), PEPPSI Pd-NHC 5-8 (1 mol \%), KOAc (1 mmol), DMAc $(2 \mathrm{~mL}), 80-130^{\circ} \mathrm{C}, 1$ or $21 \mathrm{~h}$. Product purity was checked by GC and NMR. bYields were calculated according to aryl bromides.

of 4-bromoacetophenone, $\mathrm{C}-\mathrm{C}$ bond formation (2-butyl-5phenylthiophene) was achieved in $97 \%$ yield using catalyst 8 at $110{ }^{\circ} \mathrm{C}$ with a reaction time of $1 \mathrm{~h}$ (Table 1 , entry 8 ). When bromobenzene was used with catalyst 7 at $80{ }^{\circ} \mathrm{C}$ for $21 \mathrm{~h}$, the product 2-butyl-5-phenylfuran was obtained in 71\% yield. By increasing the reaction temperature by 10 degree centigrade, as shown in entry 10, the result showed a reaction yield that was $13 \%$ higher than that of entry 9 . However, when we further increased the temperature by more than 30 degrees to $110{ }^{\circ} \mathrm{C}$, a maximum yield of $98 \%$ was obtained (Table 1 , entry 11 ). In the reaction catalyzed by $\mathbf{5}, 2$-butyl-5-(4-methoxyphenyl)thiophene was obtained in $79 \%$ yield (Table 1, entry 12 ).

\section{Catalytic activity of synthesized compounds in Suzuki-Miyaura cross-coupling reaction}

The Suzuki-Miyaura cross-coupling reaction, which has mostly been performed in organic solvents until recently, can now be performed using green solvents under mild conditions [2934]. We used $\mathrm{H}_{2} \mathrm{O}$ with DMF as solvents in different proportions in this work. We preferred to use a $1: 1$ ratio in the Suzuki-Miyaura reaction as there was not much difference between the obtained results when the ratios used were $3: 1$ or 1:1. To optimize the reaction conditions, a series of experiments with different bases such as $\mathrm{KOH}, \mathrm{NaOH}$ and $\mathrm{K}_{2} \mathrm{CO}_{3}$ were conducted at different temperatures to provide the coupling of the $\mathrm{C}-\mathrm{C}$ bond of different substrates with phenylboronic acid. The best results were obtained with the base $\mathrm{KOH}$. We also employed different time periods ranging from 1 to $3 \mathrm{~h}$. When the reaction time was extended, the yield increased in a linear manner.
The Suzuki-Miyaura reaction was carried out using electronrich (4-chloroanisole, 4-chlorotoluene), electron-poor (4-chloroacetophenone, 4-chloronitrobenzene) and electronneutral (chlorobenzene) substrates. We studied the catalytic activity of compound 1 regarding $\mathrm{C}-\mathrm{C}$ bond coupling of 4-iodoacetophenone as a substrate with phenylboronic acid (Table 2, entry 2). This catalytic system showed a better performance for aryl iodide than for aryl chlorides except chlorobenzene (Table 2, entries 1-17). 4-Acetylbiphenyl was obtained in $99 \%$ yield and $100 \%$ conversion at $80{ }^{\circ} \mathrm{C}$ and $1 \mathrm{~h}$ (Table 2 , entry 2). The best results were obtained when chlorobenzene was used as a substrate (Table 2, entries 18-21) whereas least favorable results were obtained when the electron-poor substrates were used. Among the employed carbene precursors, compound 4 gave the best result to acquire the 4-nitrobiphenyl product (Table 2, entries 8 and 9). Compounds 2 and $\mathbf{4}$ gave very good results to get the 4-methoxybiphenyl product from among the used carbene precursors (Table 2, entries 11 and 13).

Melvin et al. found the coupling of phenylboronic acid with 4-chlorotoluene with a yield of approximately $45 \%$ within 90 minutes at room temperature and reaction conditions of $1.0 \mathrm{~mol} \%$ PEPPSI-IPr, $\mathrm{K}_{2} \mathrm{CO}_{3}$, MeOH/THF (19:1). They obtained the same coupling product with a yield of around $50 \%$ when they changed the amount of PEPPSI-IPr to $0.5 \mathrm{~mol} \%$, the base to $\mathrm{KO} t$ - $\mathrm{Bu}$ and extended the reaction time to $2 \mathrm{~h}$ [35]. However, we obtained the same product in much higher yields such as 90 and $93 \%$ under reaction conditions of $1 \mathrm{~mol} \%$ of $\mathrm{Pd}(\mathrm{OAc})_{2}, 1 \mathrm{~mol} \%$ of $\mathbf{1}$ and $\mathbf{2}, \mathrm{KOH}, \mathrm{DMF} / \mathrm{H}_{2} \mathrm{O}$ within a short period of time $(1 \mathrm{~h})$ at $80{ }^{\circ} \mathrm{C}$. 


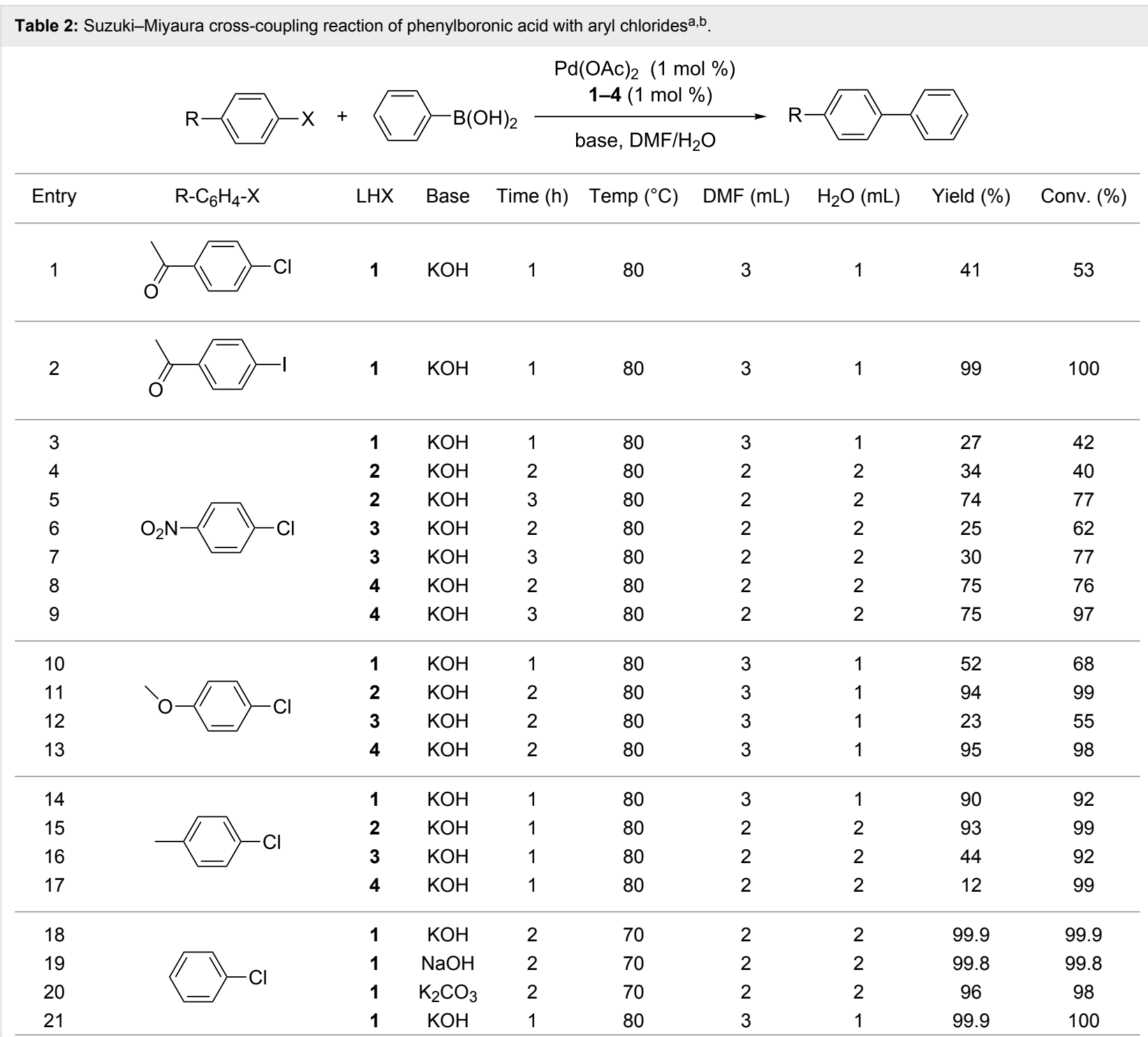

aReaction conditions: $p-\mathrm{R}-\mathrm{C}_{6} \mathrm{H}_{4} \mathrm{Cl}(1.0 \mathrm{mmol}), \mathrm{Pd}(\mathrm{OAc})_{2}(1.0 \mathrm{~mol} \%)$, phenylboronic acid $(1.5 \mathrm{mmol})$, base $(2.0 \mathrm{mmol}), 1-4(1 \mathrm{~mol} \%), \mathrm{DMF} / \mathrm{H}_{2} \mathrm{O}$,

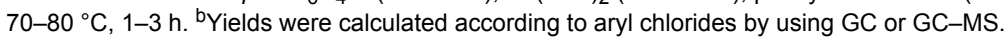

The synthesized carbene precursors consist of an electronneutral group (benzyl), electron-donating group (3-methylbenzyl) and electron-withdrawing group ( $N$-methylphthalimide) on the benzimidazolium salts. These groups are important for the catalytic performance and to understand the electronic effect of the ligands. In the presence of the catalysts formed in the in situ medium, the coupling of 4-methoxy-1-chlorobenzene with 2,5-dimethoxyphenylboronic acid was performed with overall low yields (Table 3, entries 1-4). While carbene precursor 2 showed the lowest catalytic activity, 3 gave the highest catalytic activity (Table 3, entries 2 and 3 ). We acquired excellent catalytic activity results using 4-tert-butylphenylboronic acid which is a derivative of phenylboronic acid (Table 3, entries 5-8). All compounds were found to be very effective for this coupling reaction and the product yield was between $94-100 \%$.
The $\mathrm{C}-\mathrm{C}$ bond formation of thianaphthene-2-boronic acid with 4-chloronitrobenzene using an in situ formed Pd-NHC complex as catalyst resulted in low yields and conversions (Table 3, entries 9-12). The usage of the morpholinoethyl substituted benzimidazolium compound 4 with $\mathrm{Pd}(\mathrm{OAc})_{2}$ resulted in higher yields of 2-(4-nitrophenyl)benzo[b]thiophene compared to the usage of compounds $\mathbf{1}-\mathbf{3}$.

Generally, the PEPPSI Pd-NHC complexes showed similar catalytic activity with in situ formed $\mathrm{Pd}-\mathrm{NHC}$ complexes under the same experiment conditions (Table 3 and Table 4). The 2-morpholinoethyl substituted $\mathrm{Pd}-\mathrm{NHC}$ complex $\mathbf{8}$, on the other hand, displayed very low activity compared to the other three complexes for the coupling of 2,5-dimethoxyphenylboronic acid with 4-methoxy-1-chlorobenzene (Table 4, entry 4). High 
Table 3: Suzuki-Miyaura cross-coupling reaction of boronic acid derivatives with aryl halides ${ }^{a, b}$

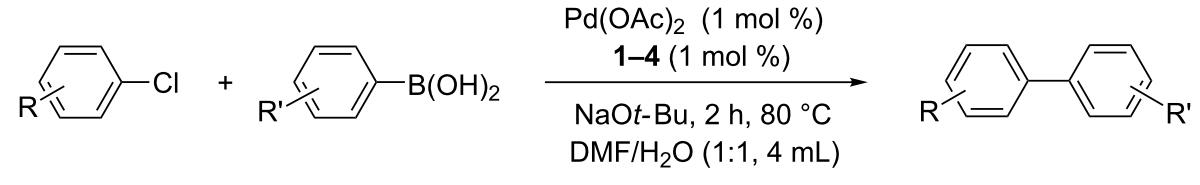

\begin{tabular}{|c|c|c|c|c|c|c|}
\hline Entry & Aryl halide & Derivatives of boronic acid & LHX & Product & Yield (\%) & Conv. (\%) \\
\hline 1 & & & 1 & & 35 & 68 \\
\hline 2 & & & 2 & & 15 & 26 \\
\hline 3 & & & 3 & & 77 & 80 \\
\hline 4 & & & 4 & & 24 & 33 \\
\hline 5 & & & 1 & & 94 & 96 \\
\hline 6 & & & 2 & & 99 & 99.7 \\
\hline 7 & & & 3 & & 98 & 99 \\
\hline 8 & & & 4 & & 99.9 & 100 \\
\hline 9 & & & 1 & & 10 & 38 \\
\hline 10 & & & 2 & & 8 & 15 \\
\hline 11 & & & 3 & & 6 & 7 \\
\hline 12 & & & 4 & & 45 & 48 \\
\hline
\end{tabular}

aReaction conditions: 4-methoxy-1-chlorobenzene, 4-chlorotoluene, 4-chloronitrobenzene (1.0 mmol), Pd(OAc) 2 (1.0 mol \%), 2,5-dimethoxyphenylboronic acid, 4-tert-butylphenylboronic acid, thianaphthene-2-boronic acid (1.5 mmol), NaOt-Bu $(2.0 \mathrm{mmol}), 1-4(1 \mathrm{~mol} \%), \mathrm{DMF} / \mathrm{H}_{2} \mathrm{O}(1: 1,4 \mathrm{~mL})$, $80^{\circ} \mathrm{C}, 2 \mathrm{~h}$. bYields were calculated according to aryl chlorides by using GC or GC-MS.

Table 4: Suzuki-Miyaura cross-coupling reaction of boronic acid derivatives with aryl chlorides ${ }^{a, b}$.

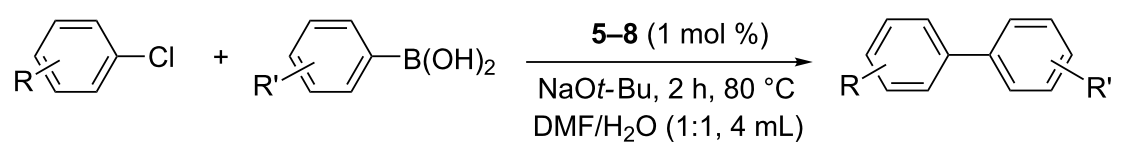

\begin{tabular}{|c|c|c|c|c|c|c|}
\hline Entry & Aryl chloride & Derivatives of boronic acid & PEPPSI Pd-NHC & Product & Yield (\%) & Conv. (\%) \\
\hline 1 & & & 5 & & 56 & 67 \\
\hline 2 & & & 6 & & 51 & 55 \\
\hline 3 & & & 7 & & 59 & 77 \\
\hline 4 & & & 8 & & 9 & 25 \\
\hline 5 & & & 5 & & 92 & 99 \\
\hline 6 & & & 6 & & 95 & 99 \\
\hline 7 & & & 7 & & 93 & 98 \\
\hline 8 & & & 8 & & 99.9 & 100 \\
\hline 9 & & & 5 & & 3 & 5 \\
\hline 10 & & & 6 & & 1 & 9 \\
\hline 11 & & & 7 & & 35 & 55 \\
\hline 12 & & & 8 & & 14 & 30 \\
\hline
\end{tabular}

aReaction conditions: 4-methoxy-1-chlorobenzene, 4-chlorotoluene, 4-chloronitrobenzene (1.0 mmol), 2,5-dimethoxyphenylboronic acid, 4-tertbutylphenylboronic acid, thianaphthene-2-boronic acid (1.5 mmol), NaOt-Bu (2.0 mmol), 5-8 (1 mol \%), DMF/ $\mathrm{H}_{2} \mathrm{O}(1: 1,4 \mathrm{~mL}), 80{ }^{\circ} \mathrm{C}, 2 \mathrm{~h} .{ }^{b} Y i e l d s$ were calculated according to aryl chlorides by using GC or GC-MS. 
yields were obtained in the presence of low amounts of catalysts 5-8 (1 mol \%) in the coupling reaction of 4-tertbutylphenylboronic acid with 4-chlorotoluene (Table 4, entries 5-8). All synthesized compounds demonstrated low activity in the coupling of thianaphthene-2-boronic acid with 4-chloronitrobenzene (Table 3, entries 9-12; Table 4, entries 9-12). In $\mathrm{C}-\mathrm{C}$ bond-forming reactions of different substrates with 2,5 dimethoxyphenylboronic acid and thianaphthene-2-boronic acid, complex 7 was found to be a good catalyst for the synthesis of biaryl systems in comparison to the other complexes. We observed that compounds 4 and $\mathbf{7}$ were more effective than the other compounds as catalyst (Table 3, entry 12; Table 4 entry 11).

\section{Conclusion}

In the present study, a series of benzimidazolium salts (1-4) and PEPPSI Pd-NHC complexes (5-8) were successfully synthesized and their structures were confirmed via ${ }^{1} \mathrm{H}$ and ${ }^{13} \mathrm{C}\left\{{ }^{1} \mathrm{H}\right\}$ NMR, ESI-FTICR-MS (for 2, 4, 6-8), UV-vis, FTIR and elemental analysis. All the compounds exhibited good solubility in organic solvents and were tested in both arylation (for 5-8) and Suzuki-Miyaura cross-coupling (for 1-8) reactions. Pd-catalyzed direct intermolecular arylation was investigated using electron-poor, electron-rich or electron-neutral substrates. In general, an electron-neutral group was found to be more effective in the formation of biaryl product. Both in situ generated Pd-NHC and PEPPSI Pd-NHC complexes as catalysts were studied in Suzuki-Miyaura cross-coupling reactions without an inert atmosphere. Both complex types were quite effective in the coupling of 4-chlorotoluene with 4-tertbutylphenylboronic acid.

\section{Supporting Information}

\section{Supporting Information File 1 \\ Experimental section. \\ [http://www.beilstein-journals.org/bjoc/content/ supplementary/1860-5397-12-9-S1.pdf]}

\section{Acknowledgments}

This work was financially supported by TUBITAK (1059B141400496) and Erciyes University Research Fund. We thank Dr Nial Wheate and Zehra Elgundi (University of Sydney) for useful comments and critical reading of the paper.

\section{References}

1. Wanzlick, H.-W.; Schönherr, H.-J. Angew. Chem., Int. Ed. Engl. 1968, 7, 141-142. doi:10.1002/anie.196801412

2. Öfele, K. J. Organomet. Chem. 1968, 12, P42-P43.

doi:10.1016/S0022-328X(00)88691-X
3. Mangalum, A.; McMillen, C. D.; Tennyson, A. G. Inorg. Chim. Acta 2015, 426, 29-38. doi:10.1016/j.ica.2014.11.003

4. Akkoç, S.; Gök, Y.; Akkurt, M.; Tahir, M. N. Inorg. Chim. Acta 2014, 413, 221-230. doi:10.1016/j.ica.2014.01.015

5. Akkoç, S.; Gök, Y. Appl. Organomet. Chem. 2014, 28, 854-860. doi:10.1002/aoc.3220

6. Serrano, J. L.; Pérez, J.; García, L.; Sánchez, G.; García, J.; Lozano, P.; Zende, V.; Kapdi, A. Organometallics 2015, 34, 522-533. doi:10.1021/om501160n

7. Lee, J.-Y.; Ghosh, D.; Lee, J.-Y.; Wu, S.-S.; Hu, C.-H.; Liu, S.-D.; Lee, H. M. Organometallics 2014, 33, 6481-6492. doi:10.1021/om500834y

8. Hashmi, A. S. K.; Lothschütz, C.; Böhling, C.; Hengst, T.; Hubbert, C.; Rominger, F. Adv. Synth. Catal. 2010, 352, 3001-3012. doi:10.1002/adsc.201000472

9. Li, Y.; Tan, C.-P.; Zhang, W.; He, L.; Ji, L.-N.; Mao, Z.-W. Biomaterials 2015, 39, 95-104. doi:10.1016/j.biomaterials.2014.10.070

10. Haque, R. A.; Choo, S. Y.; Budagumpi, S.; Iqbal, M. A.; Al-Ashraf, A. A. Eur. J. Med. Chem. 2015, 90, 82-92. doi:10.1016/j.ejmech.2014.11.005

11. Gök, Y.; Akkoç, S.; Albayrak, S.; Akkurt, M.; Tahir, M. N. Appl. Organomet. Chem. 2014, 28, 244-251. doi:10.1002/aoc.3116

12. Boehme, C.; Frenking, G. J. Am. Chem. Soc. 1996, 118, 2039-2046. doi:10.1021/ja9527075

13. Viciu, M. S.; Navarro, O.; Germaneau, R. F.; Kelly, R. A.; Sommer, W.; Marion, N.; Stevens, E. D.; Cavallo, L.; Nolan, S. P. Organometallics 2004, 23, 1629-1635. doi:10.1021/om034319e

14. Zhang, T.; Shi, M.; Zhao, M. Tetrahedron 2008, 64, 2412-2418. doi:10.1016/j.tet.2008.01.017

15. Polshettiwar, V.; Varma, R. S. Tetrahedron 2008, 64, 4637-4643. doi:10.1016/j.tet.2008.02.098

16. Górna, M.; Szulmanowicz, M. S.; Gniewek, A.; Tylus, W.; Trzeciak, A. M. J. Organomet. Chem. 2015, 785, 92-99. doi:10.1016/j.jorganchem.2015.03.009

17. Demir, S.; Özdemir, İ.; Çetinkaya, B.; Arslan, H.; VanDerveer, D. Polyhedron 2011, 30, 195-200. doi:10.1016/j.poly.2010.10.015

18. Kantchev, E. A. B.; Ying, J. Y. Organometallics 2009, 28, 289. doi:10.1021/om8008475

19. Zhou, X.-X.; Shao, L.-X. Synthesis 2011, 3138-3142. doi:10.1055/s-0030-1260169

20. Lin, Y.-C.; Hsueh, H.-H.; Kanne, S.; Chang, L.-K.; Liu, F.-C.; Lin, I. J. B.; Lee, G.-H.; Peng, S.-M. Organometallics 2013, 32, 3859-3869. doi:10.1021/om4003297

21. O'Brien, C. J.; Kantchev, E. A. B.; Valente, C.; Hadei, N.; Chass, G. A.; Lough, A.; Hopkinson, A. C.; Organ, M. G. Chem. - Eur. J. 2006, 12, 4743-4748. doi:10.1002/chem.200600251

22. Yang, L.; Zhao, J.; Li, Y.; Ge, K.; Zhuang, Y.; Cao, C.; Shi, Y. Inorg. Chem. Commun. 2012, 22, 33-36. doi:10.1016/j.inoche.2012.05.017

23. Zhao, J.; Yang, L.; Ge, K.; Chen, Q.; Zhuang, Y.; Cao, C.; Shi, Y. Inorg. Chem. Commun. 2012, 20, 326-329. doi:10.1016/j.inoche.2012.03.041

24. Yaşar, S.; Şahin, Ç.; Arslan, M.; Özdemir, İ. J. Organomet. Chem. 2015, 776, 107-112. doi:10.1016/j.jorganchem.2014.10.047

25. Rajabi, F.; Thiel, W. R. Adv. Synth. Catal. 2014, 356, 1873-1877. doi:10.1002/adsc.201300841

26. John, A.; Modak, S.; Madasu, M.; Katari, M.; Ghosh, P. Polyhedron 2013, 64, 20-29. doi:10.1016/j.poly.2013.01.062

27. Akkoç, S.; Gök, Y. Inorg. Chim. Acta 2015, 429, 34-38. doi:10.1016/j.ica.2015.01.019 
28. Viciu, M. S.; Germaneau, R. F.; Nolan, S. P. Org. Lett. 2002, 4, 4053-4056. doi:10.1021/ol026745m

29. Kinzel, T.; Zhang, Y.; Buchwald, S. L. J. Am. Chem. Soc. 2010, 132, 14073-14075. doi:10.1021/ja1073799

30. Akkoc, S.; Gok, Y. J. Coord. Chem. 2013, 66, 1396-1404. doi:10.1080/00958972.2013.786053

31.Sun, J.; Fu, Y.; He, G.; Sun, X.; Wang, X. Appl. Catal., B 2015, 165, 661-667. doi:10.1016/j.apcatb.2014.10.072

32. Liu, D.-X.; Gong, W.-J.; Li, H.-X.; Gao, J.; Li, F.-L.; Lang, J.-P. Tetrahedron 2014, 70, 3385-3389. doi:10.1016/j.tet.2014.03.098

33. Ratniyom, J.; Chaiprasert, T.; Pramjit, S.; Yotphan, S.;

Sangtrirutnugul, P.; Srisuratsiri, P.; Kongsaeree, P.; Kiatisevi, S. J. Organomet. Chem. 2014, 752, 161-170. doi:10.1016/j.jorganchem.2013.12.015

34. Zhong, L.; Chokkalingam, A.; Cha, W. S.; Lakhi, K. S.; Su, X.; Lawrence, G.; Vinu, A. Catal. Today 2015, 243, 195-198. doi:10.1016/j.cattod.2014.08.038

35. Melvin, P. R.; Nova, A.; Balcells, D.; Dai, W.; Hazari, N.; Hruszkewycz, D. P.; Shah, H. P.; Tudge, M. T. ACS Catal. 2015, 5, 3680-3688. doi:10.1021/acscatal.5b00878

\section{License and Terms}

This is an Open Access article under the terms of the Creative Commons Attribution License

(http://creativecommons.org/licenses/by/2.0), which permits unrestricted use, distribution, and reproduction in any medium, provided the original work is properly cited.

The license is subject to the Beilstein Journal of Organic Chemistry terms and conditions:

(http://www.beilstein-journals.org/bjoc)

The definitive version of this article is the electronic one which can be found at: doi:10.3762/bjoc. 12.9 